\title{
Article \\ Design, Synthesis, and Cytotoxic Activity of Novel Natural Arylsulfonamide-Inspired Molecules
}

\author{
Wenbo Huang 1,2, Liqiao Shi 1,2, Manli Liu ${ }^{1,2}$, Zhigang Zhang ${ }^{1,2}$, Fang Liu ${ }^{1,2}$, Tong Long ${ }^{1,2}$, Shaohua Wen ${ }^{1,2}$, \\ Daye Huang ${ }^{1,2}$, Kaimei Wang ${ }^{1,2}$, Ronghua Zhou ${ }^{1,2}$, Wei Fang ${ }^{1,2, *}$, Hongtao Hu ${ }^{1,2, *}$ and Shaoyong Ke ${ }^{1,2, * D}$
}

1 Key Laboratory of Microbial Pesticides, Ministry of Agriculture and Rural Affairs, Wuhan 430064, China; huangwenbo@nberc.com (W.H.); liqiao.shi@nberc.com (L.S.); manli.liu@nberc.com (M.L.); zhigang.zhang@nberc.com (Z.Z.); fang.liu@nberc.com (F.L.); tong.long@nberc.com (T.L.); wenshaohua1985@163.com (S.W.); xiaohuangdaye@126.com (D.H.); kaimei.wang@nberc.com (K.W.); ronghua.zhou@nberc.com (R.Z.)

2 National Biopesticide Engineering Research Centre, Hubei Biopesticide Engineering Research Centre, Hubei Academy of Agricultural Sciences, Wuhan 430064, China

* Correspondence: wei.fang@nberc.com (W.F.); hzh0005@gmail.com (H.H.); shaoyong.ke@nberc.com (S.K.); Tel.: +86-27-59101919 (S.K.)

check for updates

Citation: Huang, W.; Shi, L.; Liu, M.; Zhang, Z.; Liu, F.; Long, T.; Wen, S.; Huang, D.; Wang, K.; Zhou, R.; et al. Design, Synthesis, and Cytotoxic Activity of Novel Natural Arylsulfonamide-Inspired Molecules. Molecules 2022, 27, 1479. https:// doi.org/10.3390/molecules27051479

Academic Editor: Claudiu T. Supuran

Received: 14 January 2022

Accepted: 16 February 2022

Published: 22 February 2022

Publisher's Note: MDPI stays neutral with regard to jurisdictional claims in published maps and institutional affiliations.

Copyright: (C) 2022 by the authors. Licensee MDPI, Basel, Switzerland. This article is an open access article distributed under the terms and conditions of the Creative Commons Attribution (CC BY) license (https:// creativecommons.org/licenses/by/ $4.0 /)$.

\begin{abstract}
Primary arylsulfonamide functional groups feature prominently in diverse pharmaceuticals However, natural arylsulfonamides are relatively infrequent. In this work, two novel arylsulfonamide natural products were first synthesized, and then a series of novel molecules derived from natural arylsulfonamides were designed and synthesized, and their in vitro cytotoxic activities against A875, HepG2, and MARC145 cell lines were systematically evaluated. The results indicate that some of these arylsulfonamide derivatives exhibit significantly good cytotoxic activity against the tested cell lines compared with the control 5-fluorouracil (5-FU), such as compounds 101, 10p, 10q, and 10r. In particular, the potential molecule 10q, containing a carbazole moiety, exhibited the highest inhibitory activity against all tested cell lines, with $\mathrm{IC}_{50}$ values of $4.19 \pm 0.78,3.55 \pm 0.63$, and $2.95 \pm 0.78 \mu \mathrm{g} / \mathrm{mL}$, respectively. This will offer the potential to discover novel drug-like compounds from the sparsely populated area of natural products that can lead to effective anticancer agents.
\end{abstract}

Keywords: natural arylsulfonamides; derivatives; synthesis; biological evaluation; SARs

\section{Introduction}

Natural products (NPs) and their molecular scaffolds have a long tradition of offering chemists a range of uncharted chemotypes as valuable starting points for the development of novel drugs [1-3], and have also been a major source of anticancer drug discovery [4-7].

Sulfonamides have a functional group $\left(\mathrm{R}-\mathrm{SO}_{2}-\mathrm{NH}_{2}\right)$ called the sulfonamide group; sulfonamide scaffolds are also very important structural motifs that are present in diverse pharmaceuticals (Figure 1), showing important and extensive biological activities, such as antitumor [8-12], anti-inflammatory [13,14], and antiviral activities [15,16]. However, due to the structural particularity, natural products that contain a primary sulfonamide group in their structures are rare. Sulfadixiamycin A, (-)-altemicidin, and psammaplin C are a few examples of natural products that contain the structure of a sulfonamide moiety $[17,18]$ (Figure 1).

Recently, sargassulfamide A, bearing a rare and unique sulfonamide group, was isolated from the seaweed Sargassum naozhouense [19]. Almost simultaneously, another novel arylsulfonamide natural product was isolated together with sargassulfamide A from the roots and rhizomes of Tupistra chinensis Baker [20], whereas the result of in vitro cytotoxic activity in the human cancer cell lines indicated that the novel arylsulfonamide natural products displayed weak cytotoxicity. 


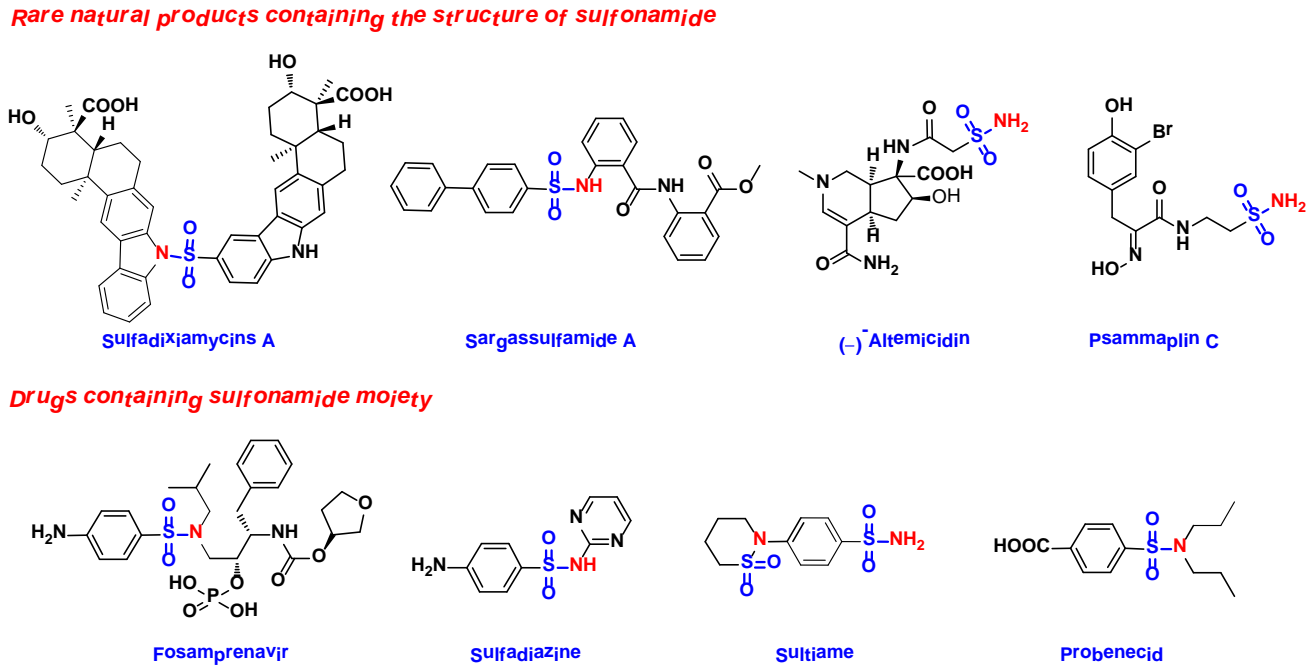

Figure 1. Prototypical natural products and drugs containing a sulfonamide group.

Natural products are among the most important sources of the lead compounds in drug discovery; however, most of them cannot be used as drugs directly. In addition, owing to their low fermentation and extraction levels, further research exploring the potential bioactivity of some natural compounds has been seriously limited. Accordingly, structural optimization and derivation of natural products becomes a powerful strategy for improving the efficiency and success rate of NP-based drug development. Our research group has committed to discovering highly active compounds from natural products [21-26], so the rare natural product sargassulfamide A, bearing a privileged scaffold of arylsulfonamide, aroused our interest. It is well known that molecular skeletons determine whether molecules have bioactivity; despite the natural arylsulfonamide sargassulfamide A being less effective against the human cancer cell lines, we wondered whether we could modulate or improve the activities of these analogues of natural products by changing the position of the amide unit and pharmacophore hybridization.

Meanwhile, aryls and hetero-aryls are important pharmacological units that always increase the potential bioactivity of corresponding molecules [27-29]. Hence, several different types of (hetero)aryl groups-including biphenyl, diphenyl ether, and heterocycleswere selected to construct diversity molecules, and theses selected aromatic aryl amines $\left(\mathrm{Ar}^{1} \mathrm{NH}_{2}\right)$ and aryl acids $\left(\mathrm{Ar}^{2} \mathrm{COOH}\right)$ are usually classical pharmacological units. Taking into account the above considerations, we wish herein to report the molecule design, convenient synthesis, and biological evaluation of a series of novel natural arylsulfonamideinspired molecules (Figure 2).

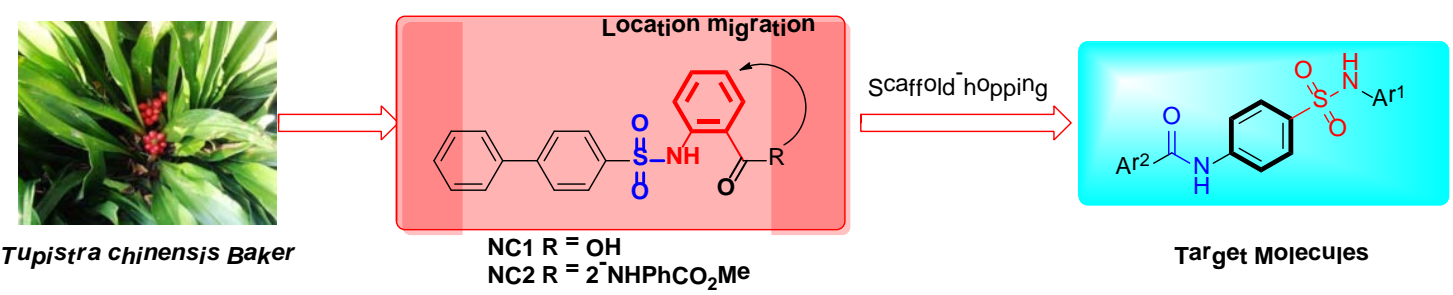

Figure 2. Design strategy of natural arylsulfonamide-inspired molecules.

In this study, sargassulfamide A (NC2) was used as a key starting point for the development of high-efficiency cytotoxic agents; a series of novel derivatives containing arylsulfonamide and carboxamide pharmacophores 10a-r were designed and synthesized as shown in Scheme 1, and their cytotoxic activities against several human cancer cell lines-including A875, HepG2, and MARC145—were systematically evaluated by the MTT 
colorimetric method for the first time. Beyond that, the possible structure and activity relationships are also summarized and discussed.

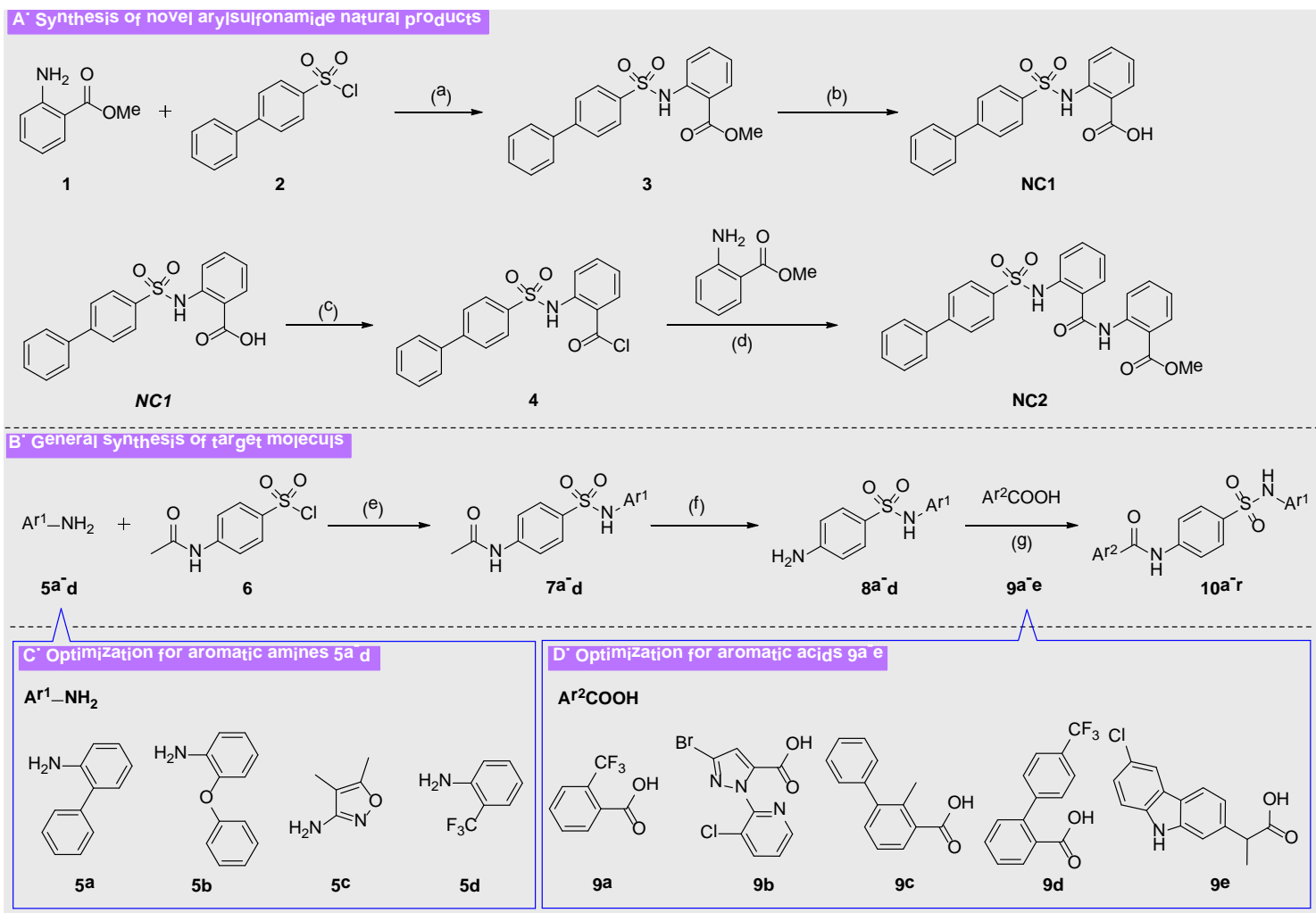

Scheme 1. Synthesis of natural arylsulfonamides and aryl-carboxamide derivatives bearing sulfonamide units 10a-r. Reagents and conditions: a. $\mathrm{Et}_{3} \mathrm{~N}, \mathrm{DCM}, \mathrm{rt} ; \mathrm{b} . \mathrm{NaOH}, \mathrm{MeOH} / \mathrm{H}_{2} \mathrm{O}, 60{ }^{\circ} \mathrm{C}$; c. $\mathrm{SOCl}_{2}$, reflux; d. $\mathrm{Et}_{3} \mathrm{~N}, \mathrm{DCM}$, rt; e. $\mathrm{Et}_{3} \mathrm{~N}, \mathrm{DCM}$, rt; f. $\mathrm{NaOH}, \mathrm{MeOH} / \mathrm{H}_{2} \mathrm{O}, 45-50{ }^{\circ} \mathrm{C}$; g. $\mathrm{Ar}^{2} \mathrm{COOH}$, $\mathrm{HOBt}, \mathrm{EDCI}, \mathrm{Et}_{3} \mathrm{~N}, \mathrm{DMF}$, r.t.

\section{Results and Discussion}

Chemistry: In this work, a series of novel aryl-carboxamide derivatives bearing sulfonamide units were designed and synthesized by integrating natural arylsulfonamides with carboxamide pharmacophores. The general synthetic route for these compounds is outlined in Scheme 1.

Synthesis of natural arylsulfonamide-containing carboxylic acid (NC1) and sargassulfamide A (NC2): First, the ethyl anthranilate 1 was treated with the biphenylsulfonyl chloride 2 via sulfonamidation reaction to yield the key intermediate arylsulfonamide 3 ; subsequently, compound $\mathbf{3}$ was conveniently hydrolyzed to the natural compound NC1, which was transformed to the corresponding acyl chloride 4 and then reacted with the ethyl anthranilate to obtain the target sargassulfamide A (NC2).

Synthesis of aryl-carboxamide derivatives bearing sulfonamide units 10a-r: The arylsulfonamide derivatives $\mathbf{7 a}-\mathbf{d}$ were prepared via the reaction of various aryl amines and 4-acetamidobenzene-1-sulfonyl chloride 6 in the presence of $\mathrm{Et}_{3} \mathrm{~N} / \mathrm{DCM}$, and then the corresponding arylsulfonamide derivatives were transformed into the intermediate arylsulfonamide derivatives $\mathbf{8 a}-\mathbf{d}$ via deacetylation reaction. Subsequently, the obtained compounds $\mathbf{8 a}-\mathbf{d}$ were condensed with various aromatic acids $\mathbf{9 a}-\mathbf{e}$ under EDCI/HOBt-promoted conditions to construct target aryl-carboxamide derivatives bearing sulfonamide units 10a-r.

Spectroscopy studies: The structures of all of the target compounds in this work gave satisfactory chemical analyses, including ${ }^{1} \mathrm{H} \mathrm{NMR},{ }^{13} \mathrm{C} \mathrm{NMR},{ }^{19} \mathrm{~F} \mathrm{NMR}$, and mass spectroscopy, and all of these spectral data were in good agreement with the proposed 
structures. For the ${ }^{1} \mathrm{H}$ NMR spectrum of all arylsulfonamide derivatives, the signals at 11.74-10.76 ppm showed a single peak, which was attributed to NH protons attached to the sulfonyl group as indicated in the molecular structures. Correspondingly, the signals in the range of 10.65-9.40 ppm were assigned to the NH protons, which attached to the carbonyl group. The signal peaks of the remaining at low fields were attributed to aromatic ring proton peaks. All of the characteristic peaks observed within the ${ }^{1} \mathrm{H}$ NMR spectra for title compounds are given in the Experimental section, and the representative ${ }^{1} \mathrm{H}$ NMR spectral analysis of the target sargassulfamide A is shown in Figure 3.

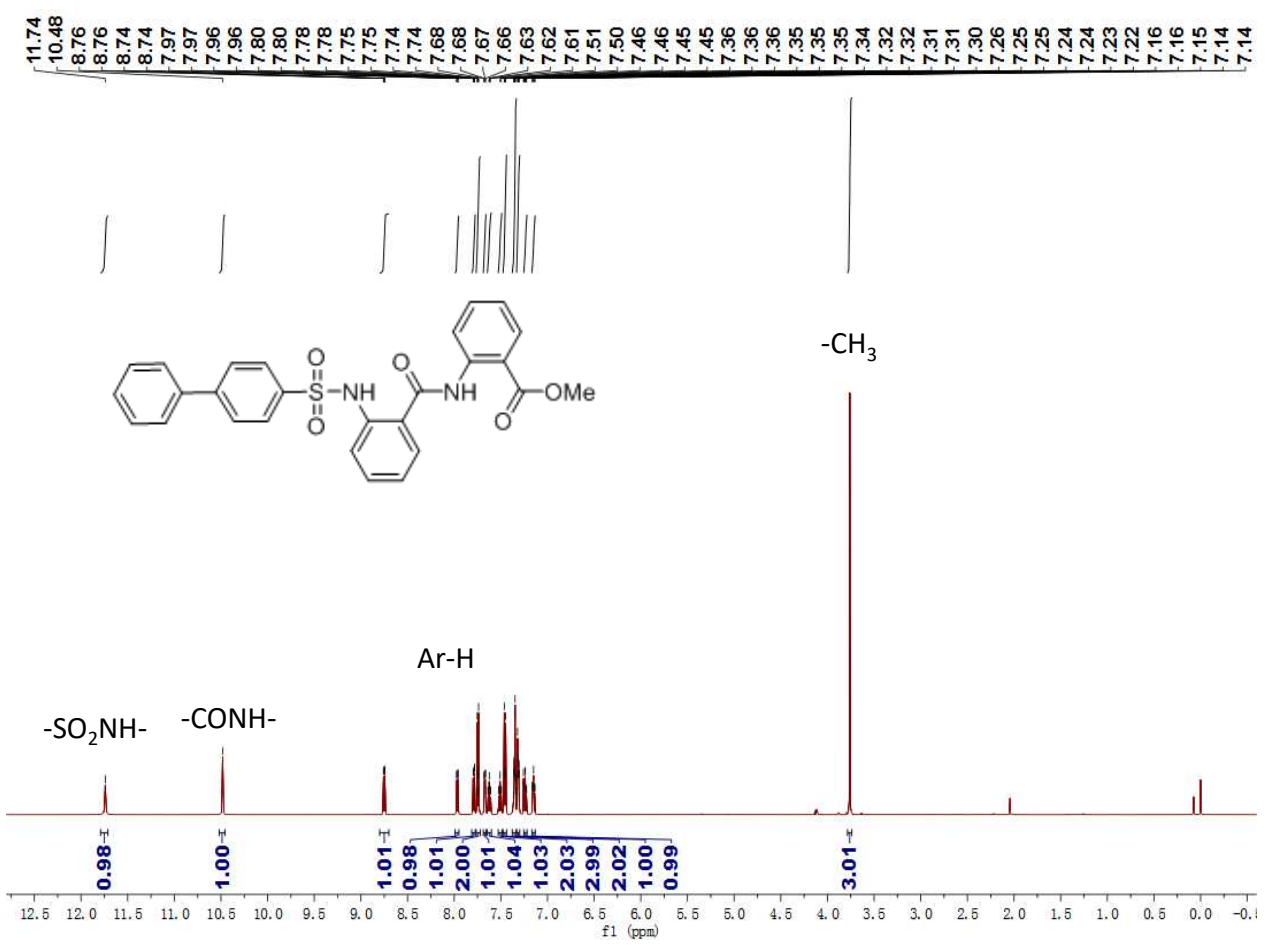

Figure 3. Representative ${ }^{1} \mathrm{H}$ NMR spectral analysis of sargassulfamide A.

Pharmacological evaluation: All target carboxamide derivatives derived from natural arylsulfonamides 10a-r were screened for their potential in vitro cytotoxic effects on A875 (human melanoma), HepG2 (human hepatocellular liver carcinoma), and MARC145 (A subclone of African green monkey kidney cell line MA-104) cell lines using the standard MTT assay [30,31], with 5-FU (5-fluorouracil) as a positive control. The results are summarized in Figure 4 and Table 1 . The $\mathrm{IC}_{50}$ value represents the drug concentration required to inhibit cell growth by $50 \%$.

Based on the preliminary screening results, we found that some of these arylsulfonamide derivatives indicated moderate-to-good inhibition activity against all tested cell lines. Notably, the compounds $\mathbf{1 0 1}, \mathbf{1 0 p}, \mathbf{1 0 q}$, and 10r exhibited significantly higher activities compared with the control at a concentration of $40 \mu \mathrm{g} / \mathrm{mL}$ (Figure 4), demonstrating that these natural-product-inspired molecules derived from sargassulfamide A could be considered as promising scaffolds for developing effective anticancer agents. 


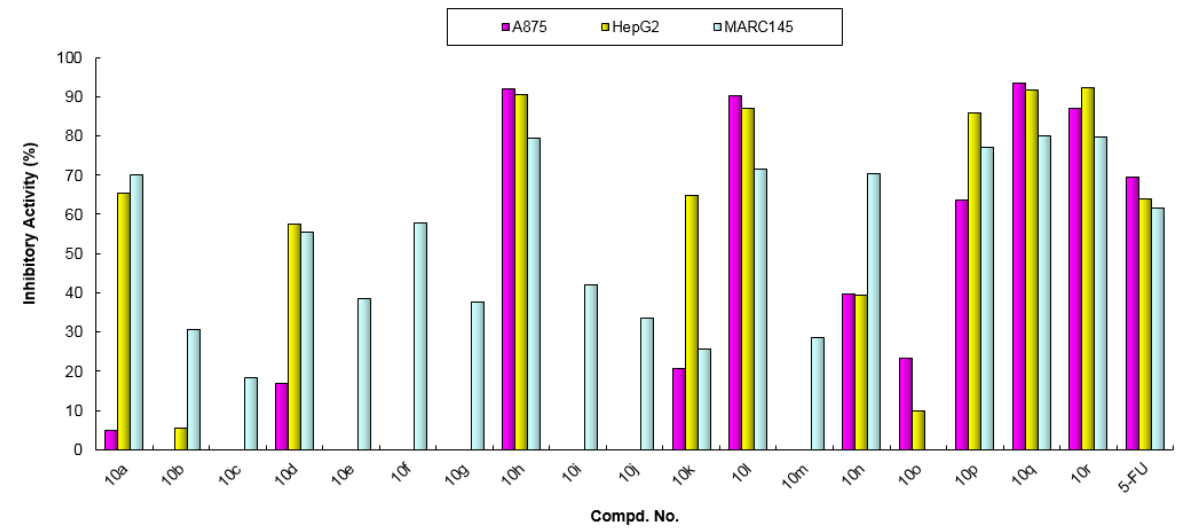

Figure 4. Inhibitory activity of compounds 10a-r at the concentration of $40 \mu \mathrm{g} / \mathrm{mL}$. Abbreviations: A875-human melanoma cell line; HepG2-human hepatocellular liver carcinoma cell line; MARC145-a subclone of African green monkey kidney cell line MA-104; 5-FU—5-fluorouracil, used as a positive control.

Table 1. In vitro cytotoxic activities of target compounds against tested cell lines.

\begin{tabular}{ccccccc}
\hline & & & & \\
\hline 5
\end{tabular}

${ }^{a} \mathrm{IC}_{50}$-Compound concentration required to inhibit tumor cell proliferation by $50 \%{ }^{b}$ Abbreviations: A875human melanoma cell line; HepG2-human hepatocellular liver carcinoma cell line; MARC145—a subclone of African green monkey kidney cell line MA-104. ${ }^{c}$ Used as a positive control.

In order to further explore their potential antitumor activity, the $\mathrm{IC}_{50}$ values of two novel arylsulfonamide natural products and a series of novel molecules derived from 
natural arylsulfonamide derivatives were all systematically evaluated. The potential inhibitory activities expressed as $\mathrm{IC}_{50}$ values for all compounds are shown in Table 1. As indicated in Table 1, the natural arylsulfonamide NC1 showed poor activity against tested cell lines, and sargassulfamide A (NC2) almost completely lost inhibitory activity $\left(\mathrm{IC}_{50}>40 \mu \mathrm{g} / \mathrm{mL}\right)$. Compounds 101, 10p 10q, and 10r, containing a trifluoromethyl unit, had higher inhibitory effects on all cell lines compared to the positive control 5-FU. It should be noted that introduction of a trifluoromethyl group to natural products and organic molecules is vitally important for lipophilicity, hydrophobicity, and metabolic stability. Hence, trifluoromethylation has played an important role in discovering highactivity drugs [32]. Compound $\mathbf{1 0 q}$, containing a carbazole scaffold, showed the strongest inhibitory effect on all three cell lines, with an $\mathrm{IC}_{50}$ of $4.19 \pm 0.78$ (A875), $3.55 \pm 0.63$ (HepG2), and $2.95 \pm 0.78$ (MARC145) $\mu \mathrm{g} / \mathrm{mL}$, which may be due to the carbazole ring being favorable for such activity. The results showed in Table 1 can further demonstrate the cytotoxic effect of arylsulfonamide derivatives as potential anticancer reagents for cancer cell lines.

Subsequently, the dose-response analysis for the high-potential compounds $\mathbf{1 0 1} \mathbf{1 0 q}$, 10r, and 5-FU was conducted, as shown in Figure 5, indicating that the cytotoxic effects of arylsulfonamide derivatives on A875 cells (left), HepG2 cells (middle), and MARC145 cells (right) are significantly concentration-dependent.
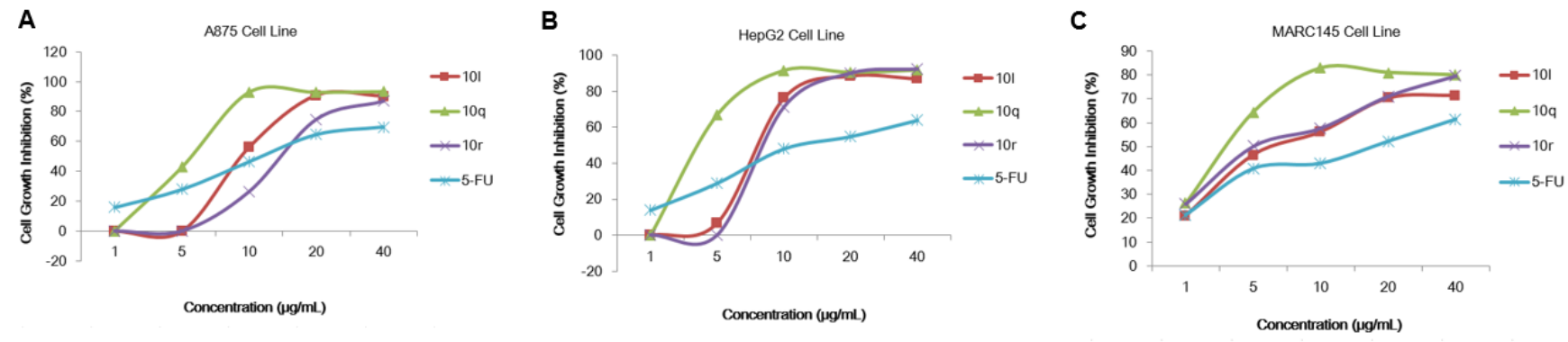

Figure 5. Dose-response analysis of cell growth inhibition activity for compounds 101, 10q, 10r, and 5-FU (positive control) against A875 cells (A), HepG2 cells (B), and MARC145 cells (C).

Structure and activity relationships (SARs): The structural evolution here was to modify natural arylsulfonamides with diverse aryl amines (5a-d) and aromatic acid scaffolds $(\mathbf{9 a}-\mathbf{e})$. According to the in vitro bioassay results presented in Figure 4 and Table 1, we obtained the preliminary structure-activity relationships (SARs) for these prepared arylsulfonamides derivatives. We concluded that the results indicate that modifying the carboxyl group of natural arylsulfonamide can yield superior cytotoxicity activity against different cancer cells. Meanwhile, changing the position of the amide unit also significantly affected the antitumor activity (Figure 6). In addition, the compounds containing trifluoromethylsubstituted arylsulfonamide derivatives presented greater cytotoxicity activity $(\mathbf{1 0 d}, \mathbf{1 0 h}$, 101, and 10p). In particular, the compounds containing a special carbazole moiety showed the highest inhibitory activity (10q and 10r), indicating that the carbazole ring is beneficial to increase the activity. It should be noted that carbazole skeletons are ubiquitous in diverse antitumor pharmaceuticals [33-35]. Above all, the obtained SARs could contribute to the discovery of potential cytotoxic agents from natural products in our subsequent research. 


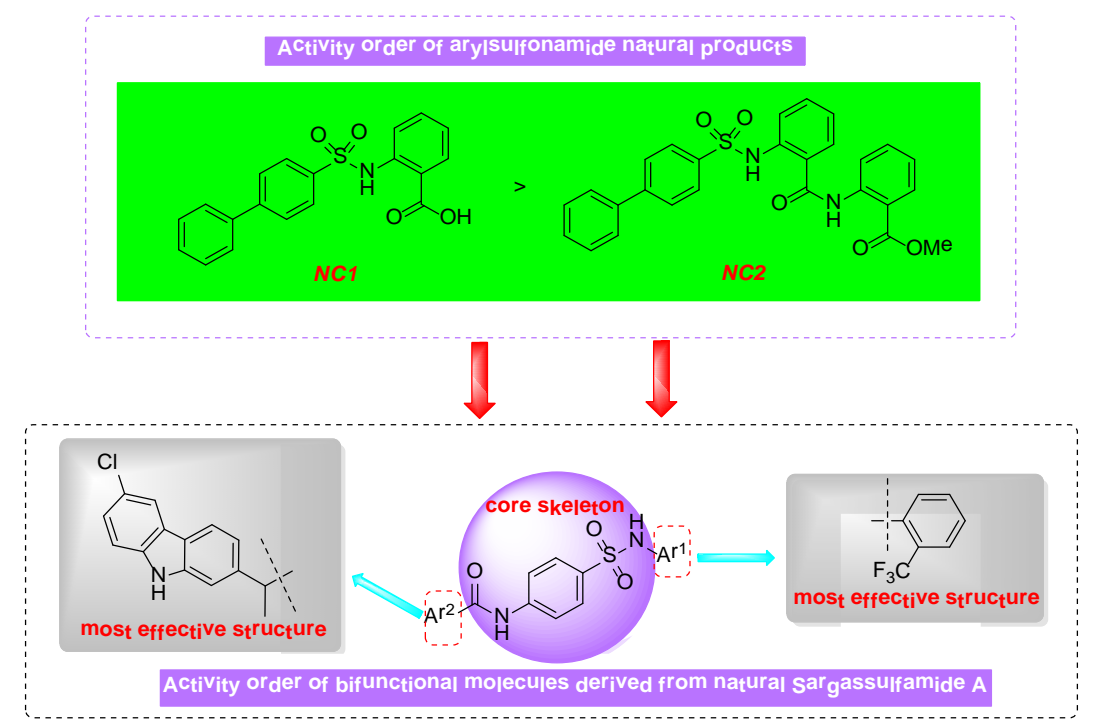

Figure 6. General SARs of target compounds.

\section{Conclusions}

In summary, we have described the molecular design, synthesis, and biological evaluation of novel arylsulfonamides inspired by natural sulfadixiamycin A. These novel natural arylsulfonamides and their derivatives were conveniently synthesized and characterized by typical spectral analyses, including ${ }^{1} \mathrm{H}$ NMR, ${ }^{13} \mathrm{C}$ NMR, ${ }^{19} \mathrm{~F}$ NMR, and ESI-MS. The preliminary in vitro bioassay indicated that some of these arylsulfonamides bearing carbazole rings displayed good cytotoxic activity against the A875 and HepG2 cancer cell lines, and the high-potential molecule $\mathbf{1 0} \mathbf{q}$ exhibited the highest inhibitory activity against all tested cell lines, with $\mathrm{IC}_{50}$ values of $4.19 \pm 0.78,3.55 \pm 0.63$, and $2.95 \pm 0.78 \mu \mathrm{g} / \mathrm{mL}$, respectively. However, the possible mechanisms for their antitumor activities still need to be explored further, and these results may promote further development of our research inspired by natural products to discover potential drug candidates.

\section{Experimental}

Instrumentation and chemicals: All reagents from commercial sources were used directly, without purification. All melting points (m.p.) were measured using a digital model X-5 apparatus (Shanghai Instrument Physical Optics Instrument Co., LTD, Shanghai, China), and were uncorrected. ${ }^{1} \mathrm{H}$ NMR, ${ }^{13} \mathrm{C}$ NMR, and ${ }^{19} \mathrm{~F}$ NMR spectra were recorded on a Bruker Avance III $600 \mathrm{MHz}$ FT-NMR spectrometer (Bruker, Billerica, MA, USA), using $\mathrm{CDCl}_{3}$ or DMSO- $d_{6}$ as the solvent and tetramethylsilane (TMS) as the internal standard. Chemical shifts are reported in $\delta$ (parts per million) values, and coupling constants ${ }^{\mathrm{n}} J$ are reported in Hz. Mass spectra were recorded on a Waters ACQUITY UPLC ${ }^{\circledR} \mathrm{H}$-Class PDA (Waters ${ }^{\circledR}$ ) instrument (Waters ${ }^{\circledR}$, Milford, MA, USA). Thin-layer chromatography (TLC) was carried out on precoated GF254 silica gel plates (Qingdao Haiyang Chemical, Qingdao, China), and spots were visualized with ultraviolet light. All commercially available starting materials and reagents were used without further purification, unless otherwise specified.

Synthetic procedures for natural compound NC1: To a solution of ethyl anthranilate $1(3.30 \mathrm{~g}, 20 \mathrm{mmol})$ and triethylamine $(4.04 \mathrm{~g}, 40 \mathrm{mmol})$ in anhydrous DCM $(40 \mathrm{~mL})$, we added 4-biphenylsulfonyl chloride $(6.06 \mathrm{~g}, 24 \mathrm{mmol})$ dropwise, which dissolved in DCM under an ice bath, and then the mixture was stirred at room temperature overnight and detected by thin-layer chromatography. After the completion of the reaction, we washed the crude mixture with saturated aqueous $\mathrm{NaHCO}_{3}$ and brine solution, and then the mixture was extracted with DCM and dried over $\mathrm{Na}_{2} \mathrm{SO}_{4}$. The obtained crude product 3 was used for the next reaction without further purification. To the obtained compound 3 in methanol ( $80 \mathrm{~mL})$, we added $20 \mathrm{~mL}$ of aqueous sodium hydroxide $(0.1 \mathrm{~mol})$, which was stirred at 
room temperature overnight. After the completion of the reaction, the mixture was adjusted to $\mathrm{pH} 3$ with diluted hydrochloric acid under an ice bath, and the precipitate was filtered and washed with a small amount of alcohol to yield the pure natural compound NC1. The physico-chemical properties for compound NC1 are as follows, and the corresponding spectrum are indicated in Supplementary Materials.

2-([1,1'-Biphenyl]-4-sulfonamido)benzoic acid (NC1), white solid, m.p. $205-207{ }^{\circ} \mathrm{C} .{ }^{1} \mathrm{H}$ NMR $\left(600 \mathrm{MHz}, \mathrm{DMSO}-\mathrm{d}_{6}, 25{ }^{\circ} \mathrm{C}\right) \delta=11.22(\mathrm{~s}, 1 \mathrm{H}), 7.94-7.89(\mathrm{~m}, 3 \mathrm{H}), 7.86(\mathrm{dd}, J=8.4,1.4 \mathrm{~Hz}$, 2H), 7.71-7.69 (m, 2H), 7.59-7.56 (m, 2H), 7.50-7.48 (m, 2H), 7.46-7.42 (m, 1H), 7.16-7.12 (m, 1H) ppm. ${ }^{13} \mathrm{C}$ NMR (151 MHz, DMSO- $\left.d_{6}, 25^{\circ} \mathrm{C}\right) \delta=170.3,145.4,140.2,138.5,137.8,135.1$, $132.1,129.6,129.2,128.1,128.0,127.6,123.8,118.8,117.1$ ppm. MS m/z $354.2=[\mathrm{M}+\mathrm{H}]^{+}$, calculated for $\mathrm{C}_{19} \mathrm{H}_{15} \mathrm{NO}_{4} \mathrm{~S} \mathrm{~m} / z=353.0$.

Synthetic procedures for natural compound NC2: Thionyl chloride $(25 \mathrm{~mL})$ was added dropwise under an ice bath to natural compound NC1 (1.59 g, $4.5 \mathrm{mmol})$; after addition, the mixture was slowly heated to $80{ }^{\circ} \mathrm{C}$ overnight, and then the reaction solution was concentrated to obtain compound 4 , which was used for the next reaction without further purification. To a mixture of ethyl anthranilate $(0.83 \mathrm{~g}, 5 \mathrm{mmol})$ and triethylamine $(1.2$ equivalents) in $\mathrm{CH}_{2} \mathrm{Cl}_{2}(25 \mathrm{~mL})$, we added compound 4 dropwise under an ice bath, and the resulting mixture was stirred at room temperature until TLC indicated that the reaction was complete. Then, $30 \mathrm{~mL}$ of water was added to the mixture, the aqueous solution was extracted with $\mathrm{CH}_{2} \mathrm{Cl}_{2}$, and the combined organic phases were washed with $\mathrm{NaHCO}_{3}$ and dried with anhydrous $\mathrm{Na}_{2} \mathrm{SO}_{4}$. After removing the volatile component, the desired natural compound NC2 was obtained. Sargassulfamide A (NC2) was subjected to isolation with silica column chromatography (eluting solution: petroleum ether/ethyl acetate $=3 / 1(v / v)$ ). The physico-chemical properties for compound NC2 are as follows, and the corresponding spectrum are indicated in Supplementary Materials.

Methyl 2-(2-([1,1'-biphenyl]-4-sulfonamido)benzamido)benzoate (NC2), white solid, m.p. 148-

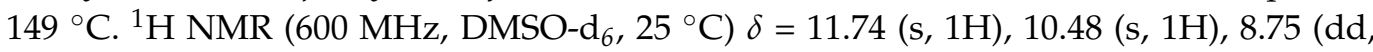
$J=8.4,0.7 \mathrm{~Hz}, 1 \mathrm{H}), 7.97(\mathrm{dd}, J=8.0,1.6 \mathrm{~Hz}, 1 \mathrm{H}), 7.79(\mathrm{dd}, J=8.3,0.9 \mathrm{~Hz}, 1 \mathrm{H}), 7.76-7.72$ $(\mathrm{m}, 2 \mathrm{H}), 7.67(\mathrm{dd}, J=7.9,1.3 \mathrm{~Hz}, 1 \mathrm{H}), 7.65-7.60(\mathrm{~m}, 1 \mathrm{H}), 7.53-7.49(\mathrm{~m}, 1 \mathrm{H}), 7.47-7.44(\mathrm{~m}$, 2H), 7.37-7.34 (m, 3H), 7.33-7.30 (m, 2H), 7.25-7.22 (m, 1H), 7.17-7.13 (m, 1H), $3.76(\mathrm{~s}, 3 \mathrm{H})$ ppm. ${ }^{13} \mathrm{C}$ NMR $\left(151 \mathrm{MHz}, \mathrm{DMSO}-d_{6}, 25^{\circ} \mathrm{C}\right) \delta=168.0,166.6,144.9,139.6,138.3,137.6,137.2$, 134.6, 133.3, 131.0, 129.5, 129.1, 128.7, 128.0, 127.7, 127.3, 126.3, 125.9, 124.5, 123.7, 122.1, 118.6, $53.0 \mathrm{ppm}$. MS $m / z 487.4=[\mathrm{M}+\mathrm{H}]^{+}$, calculated for $\mathrm{C}_{27} \mathrm{H}_{22} \mathrm{~N}_{2} \mathrm{O}_{5} \mathrm{~S} m / z=486.1$.

General synthetic procedures for aryl-carboxamide derivatives bearing sulfonamide units 10a-r: To a solution of aryl amine $(10 \mathrm{mmol})$ and triethylamine (12 mmol, 1.2 equiv.) in anhydrous DCM (20 mL), we added phenylsulfonyl chloride (12 mmol) dropwise, which dissolved in DCM under an ice bath. After the completion of the reaction, we washed the crude mixture with saturated aqueous $\mathrm{NaHCO}_{3}$ and brine solution, and then the mixture was extracted with DCM and dried over $\mathrm{Na}_{2} \mathrm{SO}_{4}$. The obtained crude products $7 \mathbf{a}-\mathbf{d}$ were used for the next reaction without further purification. The crude products 7a-d (1 equivalent) in methanol $(20 \mathrm{~mL})$ was added to $5 \mathrm{~mL}$ of aqueous sodium hydroxide (4 equivalents), and then the mixture stirred at $50{ }^{\circ} \mathrm{C}$ for $10 \mathrm{~h}$. After the completion of the reaction, the mixture was adjusted to $\mathrm{pH}$ 5-6 with diluted hydrochloric acid under an ice bath, and the precipitate was filtered and washed with a small amount of alcohol to yield $\mathbf{8 a}-\mathbf{d}$. To a solution of $\mathbf{8 a}-\mathbf{d}(1.2 \mathrm{mmol})$ in DMF $(4 \mathrm{~mL})$, we added HOBt $(1.5 \mathrm{mmol})$, EDCI $(1.5 \mathrm{mmol}), \mathrm{Et}_{3} \mathrm{~N}(2.5 \mathrm{mmol})$ and appropriate substituted acids $9 \mathrm{a}-\mathbf{e}(1.0 \mathrm{mmol})$, and then the mixture was stirred at room temperature overnight. After the completion of the reaction, water was added to the mixture, which was extracted with DCM, and the organic layer was washed with water and brine, and then dried with anhydrous $\mathrm{Na}_{2} \mathrm{SO}_{4}$. The solvent was removed to yield crude target compounds, which were purified by silica gel column chromatography (eluting solution: petroleum ether/ethyl acetate $=2 / 1(v / v)$ ) or recrystallization to yield pure compounds. The physico-chemical properties for some 
intermediates and target compounds are as follows, and the corresponding spectrum are indicated in Supplementary Materials.

$\mathrm{N}$-([1,1'-Biphenyl]-2-yl)-4-aminobenzenesulfonamide (8a), m.p. $128-129{ }^{\circ} \mathrm{C}$. MS m/z 347.3 $=[\mathrm{M}$ $+\mathrm{Na}]^{+}$, calculated for $\mathrm{C}_{18} \mathrm{H}_{16} \mathrm{~N}_{2} \mathrm{O}_{2} \mathrm{~S} \mathrm{~m} / z=324.1$.

4-Amino-N-(2-phenoxyphenyl)benzenesulfonamide (8b), m.p. 119-120 ${ }^{\circ} \mathrm{C}$. MS m/z $363.4=[\mathrm{M}+$ $\mathrm{Na}]^{+}$, calculated for $\mathrm{C}_{18} \mathrm{H}_{16} \mathrm{~N}_{2} \mathrm{O}_{3} \mathrm{~S} \mathrm{~m} / z=340.1$.

4-Amino- $\mathrm{N}$-(4,5-dimethylisoxazol-3-yl)benzenesulfonamide (8c), m.p. $162-163{ }^{\circ} \mathrm{C} . \mathrm{MS} \mathrm{m} / \mathrm{z}$ $290.3=[\mathrm{M}+\mathrm{Na}]^{+}$, calculated for $\mathrm{C}_{11} \mathrm{H}_{13} \mathrm{~N}_{3} \mathrm{O}_{3} \mathrm{~S} \mathrm{~m} / \mathrm{z}=267.1$.

4-Amino-N-(2-(trifluoromethyl)phenyl)benzenesulfonamide (8d), m.p. 95-96 ${ }^{\circ} \mathrm{C} . \mathrm{MS} m / z 317.4=[\mathrm{M}$ $+\mathrm{H}]^{+}$, calculated for $\mathrm{C}_{13} \mathrm{H}_{11} \mathrm{~F}_{3} \mathrm{~N}_{2} \mathrm{O}_{2} \mathrm{~S} \mathrm{~m} / \mathrm{z}=316.0$.

$\mathrm{N}-\left(4-\left(\mathrm{N}-\left(\left[1,1^{\prime}-\right.\right.\right.\right.$ Biphenyl]-2-yl)sulfamoyl)phenyl)-2-(trifluoromethyl)benzamide (10a), white solid, m.p. $151-152{ }^{\circ} \mathrm{C} .{ }^{1} \mathrm{H}$ NMR $\left(600 \mathrm{MHz}, \mathrm{CDCl}_{3}, \mathrm{TMS}, 25^{\circ} \mathrm{C}\right) \delta=7.93(\mathrm{~s}, 1 \mathrm{H}), 7.76(\mathrm{~d}, J=7.8 \mathrm{~Hz}$, $1 \mathrm{H}), 7.69(\mathrm{~d}, J=8.2 \mathrm{~Hz}, 1 \mathrm{H}), 7.67-7.64(\mathrm{~m}, 2 \mathrm{H}), 7.62(\mathrm{~d}, J=8.6 \mathrm{~Hz}, 3 \mathrm{H}), 7.50(\mathrm{~d}, J=8.7 \mathrm{~Hz}$, $2 \mathrm{H}), 7.36(\mathrm{dd}, J=5.1,1.8 \mathrm{~Hz}, 4 \mathrm{H}), 7.18(\mathrm{td}, J=7.5,0.9 \mathrm{~Hz}, 1 \mathrm{H}), 7.12(\mathrm{dd}, J=7.6,1.5 \mathrm{~Hz}$, $1 \mathrm{H}), 6.88(\mathrm{dt}, J=7.5,3.8 \mathrm{~Hz}, 2 \mathrm{H}), 6.65(\mathrm{~s}, 1 \mathrm{H}) \mathrm{ppm} .{ }^{13} \mathrm{C} \mathrm{NMR}\left(151 \mathrm{MHz}\right.$, DMSO- $\left.d_{6}, 25^{\circ} \mathrm{C}\right)$ $\delta=165.9,141.7,137.2,135.1,134.5,134.4,133.4,132.4,130.7,130.4,129.2,128.8,128.7,128.5$, $128.4,128.2,127.2,126.7,125.3,123.4(\mathrm{q}, J=274.8 \mathrm{~Hz}), 122.0,119.6 .{ }^{19} \mathrm{~F} \mathrm{NMR}(565 \mathrm{MHz}$, DMSO- $\left.d_{6}, 25^{\circ} \mathrm{C}\right) \delta=-58.8$. MS $m / z 497.3=[\mathrm{M}+\mathrm{H}]^{+}$, calculated for $\mathrm{C}_{26} \mathrm{H}_{19} \mathrm{~F}_{3} \mathrm{~N}_{2} \mathrm{O}_{3} \mathrm{~S}$ $m / z=496.1$.

$\mathrm{N}$-(4-(N-(2-Phenoxyphenyl)sulfamoyl)phenyl)-2-(trifluoromethyl)benzamide (10b), white solid, m.p. $161-162{ }^{\circ} \mathrm{C} .{ }^{1} \mathrm{H}$ NMR $\left(600 \mathrm{MHz}\right.$, DMSO-d $\left.6,25^{\circ} \mathrm{C}\right) \delta=10.93(\mathrm{~s}, 1 \mathrm{H}), 9.85(\mathrm{~s}, 1 \mathrm{H}), 7.88$ $(\mathrm{d}, J=7.8 \mathrm{~Hz}, 1 \mathrm{H}), 7.82(\mathrm{t}, J=7.5 \mathrm{~Hz}, 1 \mathrm{H}), 7.74(\mathrm{t}, J=8.1 \mathrm{~Hz}, 4 \mathrm{H}), 7.70-7.66(\mathrm{~m}, 2 \mathrm{H}), 7.42$ $(\mathrm{d}, J=7.5 \mathrm{~Hz}, 1 \mathrm{H}), 7.28(\mathrm{t}, J=7.8 \mathrm{~Hz}, 2 \mathrm{H}), 7.12-7.07(\mathrm{~m}, 3 \mathrm{H}), 6.71(\mathrm{dd}, J=7.6,1.5 \mathrm{~Hz}, 1 \mathrm{H})$, $6.64(\mathrm{~d}, J=8.4 \mathrm{~Hz}, 2 \mathrm{H}) \mathrm{ppm} .{ }^{13} \mathrm{C}$ NMR $\left(151 \mathrm{MHz}, \mathrm{DMSO}-d_{6}, 25^{\circ} \mathrm{C}\right) \delta=171.2,161.3,154.8$, $147.8,140.9,140.1,138.0,135.6,134.9,134.8,133.8,133.1,133.0,131.7,131.2,131.0,129.0$ $(\mathrm{q}, J=273.3 \mathrm{~Hz}), 128.8,128.6,124.5,123.7,123.6 .{ }^{19} \mathrm{~F}$ NMR $\left(565 \mathrm{MHz}, \mathrm{DMSO}-d_{6}, 2{ }^{\circ} \mathrm{C}\right)$ $\delta=-53.1$. MS $m / z 513.5=[\mathrm{M}+\mathrm{H}]^{+}$, calculated for $\mathrm{C}_{26} \mathrm{H}_{19} \mathrm{~F}_{3} \mathrm{~N}_{2} \mathrm{O}_{4} \mathrm{~S} m / z=512.1$.

$\mathrm{N}$-(4-(N-(4,5-Dimethylisoxazol-3-yl)sulfamoyl)phenyl)-2-(trifluoromethyl)benzamide (10c), white solid, m.p. $183-184{ }^{\circ} \mathrm{C} .{ }^{1} \mathrm{H}$ NMR $\left(600 \mathrm{MHz}\right.$, DMSO-d $\left.6,25^{\circ} \mathrm{C}\right) \delta=10.99(\mathrm{~s}, 1 \mathrm{H}), 10.65(\mathrm{~s}$, $1 \mathrm{H}), 7.89-7.84(\mathrm{~m}, 5 \mathrm{H}), 7.82(\mathrm{t}, J=7.5 \mathrm{~Hz}, 1 \mathrm{H}), 7.74(\mathrm{t}, J=7.5 \mathrm{~Hz}, 2 \mathrm{H}), 2.23(\mathrm{~s}, 3 \mathrm{H}), 1.80$ $(\mathrm{s}, 3 \mathrm{H}) \mathrm{ppm} .{ }^{13} \mathrm{C}$ NMR $\left(151 \mathrm{MHz}\right.$, DMSO- $\left.d_{6}, 25^{\circ} \mathrm{C}\right) \delta=166.6,166.2,157.2,143.3,136.1$, $134.8,133.2,130.9,129.0,128.9,127.0,126.4,124.2(\mathrm{q}, J=273.3 \mathrm{~Hz}), 119.7,105.0,11.2,6.4$. ${ }^{19} \mathrm{~F}$ NMR $\left(565 \mathrm{MHz}\right.$, DMSO- $\left.d_{6}, 25^{\circ} \mathrm{C}\right) \delta=-57.9$. MS $m / z 440.3=[\mathrm{M}+\mathrm{H}]^{+}$, calculated for $\mathrm{C}_{19} \mathrm{H}_{16} \mathrm{~F}_{3} \mathrm{~N}_{3} \mathrm{O}_{4} \mathrm{~S} m / z=439.0$.

2-(Trifluoromethyl)-N-(4-(N-(2-(trifluoromethyl)phenyl)sulfamoyl)phenyl)benzamide (10d), white solid, m.p. $128-129{ }^{\circ} \mathrm{C} .{ }^{1} \mathrm{H}$ NMR $\left(600 \mathrm{MHz}, \mathrm{DMSO}_{-} \mathrm{d}_{6}, 25^{\circ} \mathrm{C}\right) \delta=10.91(\mathrm{~s}, 1 \mathrm{H}), 9.92(\mathrm{~s}, 1 \mathrm{H})$, $8.54(\mathrm{dd}, J=4.7,1.5 \mathrm{~Hz}, 1 \mathrm{H}), 8.25(\mathrm{dd}, J=8.1,1.5 \mathrm{~Hz}, 1 \mathrm{H}), 7.83(\mathrm{~d}, J=8.7 \mathrm{~Hz}, 2 \mathrm{H}), 7.75(\mathrm{~d}$, $J=8.8 \mathrm{~Hz}, 2 \mathrm{H}), 7.71(\mathrm{dd}, J=7.9,1.1 \mathrm{~Hz}, 1 \mathrm{H}), 7.67(\mathrm{dd}, J=8.1,4.7 \mathrm{~Hz}, 1 \mathrm{H}), 7.58(\mathrm{t}, J=7.3 \mathrm{~Hz}$, $1 \mathrm{H}), 7.52(\mathrm{~s}, 1 \mathrm{H}), 7.45(\mathrm{t}, J=7.7 \mathrm{~Hz}, 1 \mathrm{H}), 7.04(\mathrm{~d}, J=8.0 \mathrm{~Hz}, 1 \mathrm{H}) \mathrm{ppm} .{ }^{13} \mathrm{C} \mathrm{NMR}(151 \mathrm{MHz}$, DMSO- $\left.d_{6}, 25^{\circ} \mathrm{C}\right) \delta=156.3,148.7,147.8,142.3,140.1,139.6,136.6,134.6,133.7,129.0,128.4$, $128.3,128.0,127.3,127.2,126.6,123.7(\mathrm{q}, J=274.8 \mathrm{~Hz}), 120.5,111.8 .{ }^{19} \mathrm{~F}$ NMR $(565 \mathrm{MHz}$, DMSO- $\left.d_{6}, 25^{\circ} \mathrm{C}\right) \delta=-58.0$. MS $m / z 489.3=[\mathrm{M}+\mathrm{H}]^{+}$, calculated for $\mathrm{C}_{21} \mathrm{H}_{14} \mathrm{~F}_{6} \mathrm{~N}_{2} \mathrm{O}_{3} \mathrm{~S}$ $m / z=488.0$.

N-(4-(N-([1,1'-Biphenyll-2-yl)sulfamoyl)phenyl)-3-bromo-1-(3-chloropyridin-2-yl)-1H-pyrazole-5carboxamide (10e), white solid, m.p. $156-157{ }^{\circ} \mathrm{C} .{ }^{1} \mathrm{H}$ NMR $\left(600 \mathrm{MHz}, \mathrm{DMSO}-\mathrm{d}_{6}, 25^{\circ} \mathrm{C}\right)$ $\delta=10.88(\mathrm{~s}, 1 \mathrm{H}), 9.44(\mathrm{~s}, 1 \mathrm{H}), 8.55(\mathrm{dd}, J=4.7,1.5 \mathrm{~Hz}, 1 \mathrm{H}), 8.27-8.23(\mathrm{~m}, 1 \mathrm{H}), 7.70(\mathrm{~d}$, $J=8.8 \mathrm{~Hz}, 2 \mathrm{H}), 7.69-7.66(\mathrm{~m}, 1 \mathrm{H}), 7.53(\mathrm{~d}, J=8.8 \mathrm{~Hz}, 2 \mathrm{H}), 7.51(\mathrm{~s}, 1 \mathrm{H}), 7.36-7.32(\mathrm{~m}, 2 \mathrm{H})$, $7.31(\mathrm{dt}, J=5.5,2.3 \mathrm{~Hz}, 1 \mathrm{H}), 7.29-7.27(\mathrm{~m}, 3 \mathrm{H}), 7.26-7.22(\mathrm{~m}, 3 \mathrm{H}), 7.07-7.03(\mathrm{~m}, 1 \mathrm{H}) \mathrm{ppm}$. ${ }^{13} \mathrm{C}$ NMR $\left(151 \mathrm{MHz}, \mathrm{DMSO}-d_{6}, 25^{\circ} \mathrm{C}\right) \delta=156.3,148.7,147.8,141.9,140.1,139.7,139.2,139.0$, $136.4,133.7,131.4,129.7,128.5,128.2,128.0,127.5,127.3,127.2,127.1,120.4,111.8$ ppm. MS $m / z 608.2=[\mathrm{M}+\mathrm{H}]^{+}$, calculated for $\mathrm{C}_{27} \mathrm{H}_{19} \mathrm{BrClN}_{5} \mathrm{O}_{3} \mathrm{~S} m / z=607.0$. 
3-Bromo-1-(3-chloropyridin-2-yl)-N-(4-(N-(2-phenoxyphenyl)sulfamoyl)phenyl)-1H-pyrazole-5carboxamide (10f), white solid, m.p. $177-178{ }^{\circ} \mathrm{C} .{ }^{1} \mathrm{H}$ NMR $\left(600 \mathrm{MHz}, \mathrm{DMSO}-\mathrm{d}_{6}, 25{ }^{\circ} \mathrm{C}\right)$ $\delta=10.82(\mathrm{~s}, 1 \mathrm{H}), 10.82(\mathrm{~s}, 1 \mathrm{H}), 9.84(\mathrm{~s}, 1 \mathrm{H}), 8.54(\mathrm{dd}, J=4.7,1.4 \mathrm{~Hz}, 1 \mathrm{H}), 8.26(\mathrm{dd}, J=8.1$, $1.3 \mathrm{~Hz}, 1 \mathrm{H}), 7.71-7.60(\mathrm{~m}, 5 \mathrm{H}), 7.48(\mathrm{~s}, 1 \mathrm{H}), 7.36(\mathrm{dd}, J=7.8,1.7 \mathrm{~Hz}, 1 \mathrm{H}), 7.22(\mathrm{t}, J=7.9 \mathrm{~Hz}$, 2H), 7.12-7.03 (m, 3H), $6.67(\mathrm{dd}, J=7.9,1.4 \mathrm{~Hz}, 1 \mathrm{H}), 6.63-6.55(\mathrm{~m}, 2 \mathrm{H}) \mathrm{ppm} .{ }^{13} \mathrm{C} \mathrm{NMR}$ $\left(151 \mathrm{MHz}, \mathrm{DMSO}-d_{6}, 25^{\circ} \mathrm{C}\right) \delta=156.4,156.2,150.2,148.7,147.8,142.1,140.1,139.7,135.8$, $130.1,128.3,128.1,127.3,127.2,126.5,123.9,123.8,120.4,119.0,118.8,111.7$ ppm. MS $m / z$ $624.2=[\mathrm{M}+\mathrm{H}]^{+}$, calculated for $\mathrm{C}_{27} \mathrm{H}_{19} \mathrm{BrClN}_{5} \mathrm{O}_{4} \mathrm{~S} m / z=623.0$.

3-Bromo-1-(3-chloropyridin-2-yl)-N-(4-(N-(4,5-dimethylisoxazol-3-yl)sulfamoyl)phenyl)-1H-pyrazole5-carboxmide (10g), white solid, m.p. 171-172 ${ }^{\circ} \mathrm{C} .{ }^{1} \mathrm{H}$ NMR $\left(600 \mathrm{MHz}, \mathrm{DMSO}-\mathrm{d}_{6}, 25{ }^{\circ} \mathrm{C}\right)$ $\delta=10.91(\mathrm{~s}, 1 \mathrm{H}), 10.66(\mathrm{~s}, 1 \mathrm{H}), 8.53(\mathrm{dd}, J=4.7,1.5 \mathrm{~Hz}, 1 \mathrm{H}), 8.24(\mathrm{dd}, J=8.1,1.5 \mathrm{~Hz}, 1 \mathrm{H})$, $7.84-7.79(\mathrm{~m}, 4 \mathrm{H}), 7.66(\mathrm{dd}, J=8.1,4.7 \mathrm{~Hz}, 1 \mathrm{H}), 7.48(\mathrm{~s}, 1 \mathrm{H}), 2.21(\mathrm{~s}, 3 \mathrm{H}), 1.77(\mathrm{~s}, 3 \mathrm{H}) \mathrm{ppm}$. ${ }^{13} \mathrm{C}$ NMR $\left(151 \mathrm{MHz}\right.$, DMSO-d $\left.d_{6}, 25^{\circ} \mathrm{C}\right) \delta=166.3,157.1,156.3,148.7,147.8,142.4,140.1,139.7$, $135.3,128.9,128.2,127.3,127.2,120.4,111.8,105.1,11.2,6.4$ ppm. MS m/z $651.2=[\mathrm{M}+\mathrm{H}]^{+}$, calculated for $\mathrm{C}_{20} \mathrm{H}_{16} \mathrm{BrClN}_{6} \mathrm{O}_{4} \mathrm{~S} \mathrm{~m} / z=649.9$.

3-Bromo-1-(3-chloropyridin-2-yl)-N-(4-(N-(2-(trifluoromethyl)phenyl)sulfamoyl)phenyl)-1H-pyrazole5-carboxamide (10h), white solid, m.p. 181-182 ${ }^{\circ} \mathrm{C} .{ }^{1} \mathrm{H}$ NMR $\left(600 \mathrm{MHz}, \mathrm{DMSO}-\mathrm{d}_{6}, 25{ }^{\circ} \mathrm{C}\right)$ $\delta=10.91(\mathrm{~s}, 1 \mathrm{H}), 9.92(\mathrm{~s}, 1 \mathrm{H}), 8.55(\mathrm{dd}, J=4.7,1.5 \mathrm{~Hz}, 1 \mathrm{H}), 8.25(\mathrm{dd}, J=8.1,1.5 \mathrm{~Hz}, 1 \mathrm{H})$, $7.84(\mathrm{~d}, J=8.9 \mathrm{~Hz}, 2 \mathrm{H}), 7.76(\mathrm{~d}, J=8.8 \mathrm{~Hz}, 2 \mathrm{H}), 7.71(\mathrm{dd}, J=7.9,1.1 \mathrm{~Hz}, 1 \mathrm{H}), 7.67(\mathrm{dd}$, $J=8.1,4.7 \mathrm{~Hz}, 1 \mathrm{H}), 7.60-7.56(\mathrm{~m}, 1 \mathrm{H}), 7.52(\mathrm{~s}, 1 \mathrm{H}), 7.44(\mathrm{t}, J=7.7 \mathrm{~Hz}, 1 \mathrm{H}), 7.05(\mathrm{~d}, J=8.0 \mathrm{~Hz}$, $1 \mathrm{H}) \mathrm{ppm} .{ }^{13} \mathrm{C}$ NMR $\left(151 \mathrm{MHz}, \mathrm{DMSO}-d_{6}, 25^{\circ} \mathrm{C}\right) \delta=156.3,148.7,147.8,142.3,140.1,139.6$, 136.6, 134.6, 133.7, 128.9, 128.4, 128.3, 127.9, 127.5, 127.3, 127.2, 126.6, 123.7 (q, J = 273.3 Hz), $120.5,111.8 .{ }^{19} \mathrm{~F}$ NMR $\left(565 \mathrm{MHz}, \mathrm{DMSO} d_{6}, 25^{\circ} \mathrm{C}\right) \delta=-57.9 . \mathrm{MS} m / z 600.5=[\mathrm{M}+\mathrm{H}]^{+}$, calculated for $\mathrm{C}_{22} \mathrm{H}_{14} \mathrm{~F}_{3} \mathrm{BrClN}_{5} \mathrm{O}_{3} \mathrm{~S} \mathrm{~m} / z=598.9$.

N-(4-(N-([1,1'-Biphenyl]-2-yl)sulfamoyl)phenyl)-2-methyl-[1,1'-biphenyl]-3-carboxamide (10i), white solid, m.p. $197-198{ }^{\circ} \mathrm{C} .{ }^{1} \mathrm{H}$ NMR $\left(600 \mathrm{MHz}, \mathrm{DMSO}-\mathrm{d}_{6}, 25^{\circ} \mathrm{C}\right) \delta=10.79(\mathrm{~s}, 1 \mathrm{H}), 9.40$ (s, 1H), $7.83(\mathrm{~d}, J=8.7 \mathrm{~Hz}, 2 \mathrm{H}), 7.57-7.53(\mathrm{~m}, 2 \mathrm{H}), 7.51-7.46(\mathrm{~m}, 3 \mathrm{H}), 7.43-7.39(\mathrm{~m}, 2 \mathrm{H})$, 7.39-7.35 (m, 4H), 7.34-7.33 (m, 2H), 7.30-7.27 (m, 2H), 7.27-7.23 (m, 3H), 7.11-7.08 (m, 1H), 2.25 (s, 3H) ppm. ${ }^{13} \mathrm{C}$ NMR (151 MHz, DMSO-d $\left.6,25{ }^{\circ} \mathrm{C}\right) \delta=169.1,143.2,142.9,141.3$, $139.1,139.0,138.7,135.6,133.9,132.4,131.5,131.4,129.7,129.5,128.9,128.5,128.1,127.7$, $127.5,127.1,126.9,126.7,126.3,119.7,17.7 \mathrm{ppm}$. MS $m / z 519.4=[\mathrm{M}+\mathrm{H}]^{+}$, calculated for $\mathrm{C}_{32} \mathrm{H}_{26} \mathrm{~N}_{2} \mathrm{O}_{3} \mathrm{~S} m / z=518.1$.

2-Methyl-N-(4-(N-(2-phenoxyphenyl)sulfamoyl)phenyl)-[1,1'-biphenyl]-3-carboxamide (10j), white solid, m.p. $170-171{ }^{\circ} \mathrm{C} .{ }^{1} \mathrm{H}$ NMR $\left(600 \mathrm{MHz}, \mathrm{DMSO}-\mathrm{d}_{6}, 25^{\circ} \mathrm{C}\right) \delta=10.76(\mathrm{~s}, 1 \mathrm{H}), 9.84$ (s, $1 \mathrm{H}), 7.80(\mathrm{~d}, J=8.7 \mathrm{~Hz}, 2 \mathrm{H}), 7.67(\mathrm{~d}, J=8.8 \mathrm{~Hz}, 2 \mathrm{H}), 7.50-7.46(\mathrm{~m}, 3 \mathrm{H}), 7.42-7.39(\mathrm{~m}, 3 \mathrm{H})$, 7.36-7.34 (m, 3H), 7.29-7.27 (m, 2H), 7.10-7.07 (m, 3H), $6.71(\mathrm{dd}, J=7.8,1.8 \mathrm{~Hz}, 1 \mathrm{H}), 6.66$ $(\mathrm{dd}, J=8.6,0.9 \mathrm{~Hz}, 2 \mathrm{H}), 2.24(\mathrm{~s}, 3 \mathrm{H}) \mathrm{ppm} .{ }^{13} \mathrm{C}$ NMR $\left(151 \mathrm{MHz}, \mathrm{DMSO}-d_{6}, 25^{\circ} \mathrm{C}\right) \delta=169.1$, 156.6, 150.0, 143.4, 143.0, 141.3, 138.6, 135.0, 132.4, 130.1, 129.6, 129.5, 128.8, 128.7, 128.3, $127.7,127.0,126.7,126.3,126.1,124.1,123.9,119.6,118.9,118.8,17.7$ ppm. MS m/z 535.5 = [M $+\mathrm{H}]^{+}$, calculated for $\mathrm{C}_{32} \mathrm{H}_{26} \mathrm{~N}_{2} \mathrm{O}_{4} \mathrm{~S} \mathrm{~m} / z=534.1$.

N-(4-(N-(4,5-Dimethylisoxazol-3-yl)sulfamoyl)phenyl)-2-methyl-[1,1'-biphenyl]-3-carboxamide (10k), white solid, m.p. $156-157^{\circ} \mathrm{C} .{ }^{1} \mathrm{H}$ NMR $\left(600 \mathrm{MHz}, \mathrm{DMSO}-\mathrm{d}_{6}, 25{ }^{\circ} \mathrm{C}\right) \delta=10.84(\mathrm{~s}, 1 \mathrm{H}), 10.65$ $(\mathrm{s}, 1 \mathrm{H}), 7.94(\mathrm{~d}, J=8.8 \mathrm{~Hz}, 2 \mathrm{H}), 7.87-7.84(\mathrm{~m}, 2 \mathrm{H}), 7.50-7.47(\mathrm{~m}, 3 \mathrm{H}), 7.43-7.38(\mathrm{~m}, 2 \mathrm{H})$, 7.36-7.33 (m, 3H), $2.23(\mathrm{~s}, 6 \mathrm{H}), 1.81(\mathrm{~s}, 3 \mathrm{H}) \mathrm{ppm} .{ }^{13} \mathrm{C}$ NMR $\left(151 \mathrm{MHz}, \mathrm{DMSO}-d_{6}, 25{ }^{\circ} \mathrm{C}\right)$ $\delta=169.2,166.2,157.2,143.7,142.9,141.3,138.6,134.5,132.5,131.5,129.5,128.9,128.8,127.7$, $126.7,126.3,119.6,105.0,17.7,11.2,6.4 \mathrm{ppm}$. MS $m / z 462.4=[\mathrm{M}+\mathrm{H}]^{+}$, calculated for $\mathrm{C}_{25} \mathrm{H}_{23} \mathrm{~N}_{3} \mathrm{O}_{4} \mathrm{~S} m / z=461.1$.

2-Methyl-N-(4-(N-(2-(trifluoromethyl)phenyl)sulfamoyl)phenyl)-[1,1'-biphenyl]-3-carboxamide (101), m.p. $178-180{ }^{\circ} \mathrm{C} .{ }^{1} \mathrm{H}$ NMR $\left(600 \mathrm{MHz}, \mathrm{DMSO}_{6}, 25{ }^{\circ} \mathrm{C}\right) \delta=10.84(\mathrm{~s}, 1 \mathrm{H}), 9.88(\mathrm{~s}, 1 \mathrm{H}), 7.96$ $(\mathrm{d}, J=8.7 \mathrm{~Hz}, 2 \mathrm{H}), 7.78(\mathrm{~d}, J=8.8 \mathrm{~Hz}, 2 \mathrm{H}), 7.72(\mathrm{~d}, J=7.2 \mathrm{~Hz}, 1 \mathrm{H}), 7.60(\mathrm{t}, J=7.5 \mathrm{~Hz}, 1 \mathrm{H})$, $7.50-7.44(\mathrm{~m}, 4 \mathrm{H}), 7.40(\mathrm{dd}, J=14.0,7.4 \mathrm{~Hz}, 2 \mathrm{H}), 7.36-7.33(\mathrm{~m}, 3 \mathrm{H}), 7.08(\mathrm{~d}, J=8.1 \mathrm{~Hz}, 1 \mathrm{H})$, 2.24 (s, 3H) ppm. ${ }^{13} \mathrm{C}$ NMR $\left(151 \mathrm{MHz}, \mathrm{DMSO}-d_{6}, 25^{\circ} \mathrm{C}\right) \delta=169.2,143.5,143.0,141.3,138.6$, 
$135.8,134.8,133.8,132.5,131.5,129.5,128.9,128.8,128.4,127.8,127.7,127.5,126.7,126.5$, $126.3,123.7(\mathrm{q}, J=273.3 \mathrm{~Hz}), 119.8,17.7 .{ }^{19} \mathrm{~F}$ NMR $\left(565 \mathrm{MHz}, \mathrm{DMSO}-d_{6}, 25{ }^{\circ} \mathrm{C}\right) \delta=-57.9$. MS $m / z 511.4=[\mathrm{M}+\mathrm{H}]^{+}$, calculated for $\mathrm{C}_{27} \mathrm{H}_{21} \mathrm{~F}_{3} \mathrm{~N}_{2} \mathrm{O}_{3} \mathrm{~S} m / z=510.1$.

$N-\left(4-\left(N-\left(\left[1,1^{\prime}-\right.\right.\right.\right.$ Biphenyl]-2-yl)sulfamoyl)phenyl)-4'-(trifluoromethyl)-[1,1'-biphenyl]-2-carboxamide (10m), white solid, m.p. $163-164{ }^{\circ} \mathrm{C} .{ }^{1} \mathrm{H}$ NMR $\left(600 \mathrm{MHz}, \mathrm{DMSO}-\mathrm{d}_{6}, 25{ }^{\circ} \mathrm{C}\right) \delta=10.76(\mathrm{~s}$, $1 \mathrm{H}), 9.40(\mathrm{~s}, 1 \mathrm{H}), 7.80(\mathrm{~d}, J=8.2 \mathrm{~Hz}, 2 \mathrm{H}), 7.73(\mathrm{dd}, J=7.5,1.1 \mathrm{~Hz}, 1 \mathrm{H}), 7.71-7.67(\mathrm{~m}, 3 \mathrm{H})$, 7.65-7.61(m, 3H), $7.58(\mathrm{~d}, J=7.6 \mathrm{~Hz}, 1 \mathrm{H}), 7.48(\mathrm{~d}, J=8.8 \mathrm{~Hz}, 2 \mathrm{H}), 7.35-7.28(\mathrm{~m}, 5 \mathrm{H}), 7.27-7.24$ $(\mathrm{m}, 1 \mathrm{H}), 7.21-7.17(\mathrm{~m}, 2 \mathrm{H}), 7.14(\mathrm{~d}, J=9.3 \mathrm{~Hz}, 1 \mathrm{H}) \mathrm{ppm} .{ }^{13} \mathrm{C}$ NMR $\left(151 \mathrm{MHz}, \mathrm{DMSO}-d_{6}, 25\right.$ $\left.{ }^{\circ} \mathrm{C}\right) \delta=168.3,144.6,142.9,139.1,139.0,138.6,137.0,135.6,133.8,131.3,130.9,130.6,129.7$, 129.6, 128.6, 128.5, 128.2, 127.9, 127.4, 127.2, 127.1, 126.7, 126.6, 124.7 (q, $J=272.0 \mathrm{~Hz}), 119.7$. MS $m / z 573.6=[\mathrm{M}+\mathrm{H}]^{+}$, calculated for $\mathrm{C}_{32} \mathrm{H}_{23} \mathrm{~F}_{3} \mathrm{~N}_{2} \mathrm{O}_{3} \mathrm{~S} m / z=572.1$.

N-(4-(N-(2-Phenoxyphenyl)sulfamoyl)phenyl)-4'-(trifluoromethyl)-[1,1'-biphenyl]-2-carboxamide (10n), white solid, m.p. $173-174{ }^{\circ} \mathrm{C} .{ }^{1} \mathrm{H}$ NMR $\left(600 \mathrm{MHz}, \mathrm{DMSO}-\mathrm{d}_{6}, 25{ }^{\circ} \mathrm{C}\right) \delta=10.74$ (s, $1 \mathrm{H}), 9.82(\mathrm{~s}, 1 \mathrm{H}), 7.73(\mathrm{~d}, J=8.2 \mathrm{~Hz}, 2 \mathrm{H}), 7.69-7.67(\mathrm{~m}, 1 \mathrm{H}), 7.66-7.63(\mathrm{~m}, 2 \mathrm{H}), 7.63-7.56(\mathrm{~m}$, $6 \mathrm{H}), 7.54(\mathrm{~d}, J=7.6 \mathrm{~Hz}, 1 \mathrm{H}), 7.37(\mathrm{dd}, J=7.8,1.9 \mathrm{~Hz}, 1 \mathrm{H}), 7.25-7.21(\mathrm{~m}, 2 \mathrm{H}), 7.11-7.03(\mathrm{~m}$, $3 \mathrm{H}), 6.70(\mathrm{dd}, J=7.9,1.6 \mathrm{~Hz}, 1 \mathrm{H}), 6.64(\mathrm{dd}, J=8.6,0.9 \mathrm{~Hz}, 2 \mathrm{H}) \mathrm{ppm} .{ }^{13} \mathrm{C} \mathrm{NMR}(151 \mathrm{MHz}$, DMSO- $\left.d_{6}, 25^{\circ} \mathrm{C}\right) \delta=168.3,156.6,149.9,144.7,143.1,138.6,136.9,135.1,130.9,130.7,130.1$, $129.6,128.6,128.4,128.2,126.9,125.7(q, J=3.0 \mathrm{~Hz}), 124.1(\mathrm{q}, J=272.0 \mathrm{~Hz}), 123.8,119.6$, $118.9,118.8 .{ }^{19} \mathrm{~F} \mathrm{NMR}\left(565 \mathrm{MHz}, \mathrm{DMSO}-d_{6}, 25^{\circ} \mathrm{C}\right) \delta=-60.9$. MS $m / z 589.6=[\mathrm{M}+\mathrm{H}]^{+}$, calculated for $\mathrm{C}_{32} \mathrm{H}_{23} \mathrm{~F}_{3} \mathrm{~N}_{2} \mathrm{O}_{4} \mathrm{~S} m / z=588.1$.

N-(4-(N-(4,5-Dimethylisoxazol-3-yl)sulfamoyl)phenyl)-4'-(trifluoromethyl)-[1,1'-biphenyl]-2carboxamide (10o), white solid, m.p. $199-200{ }^{\circ} \mathrm{C} .{ }^{1} \mathrm{H}$ NMR $\left(600 \mathrm{MHz}, \mathrm{DMSO}-\mathrm{d}_{6}, 25{ }^{\circ} \mathrm{C}\right)$ $\delta=10.82(\mathrm{~s}, 1 \mathrm{H}), 10.61(\mathrm{~s}, 1 \mathrm{H}), 7.78-7.76(\mathrm{~m}, 3 \mathrm{H}), 7.75-7.73(\mathrm{~m}, 3 \mathrm{H}), 7.69(\mathrm{dd}, J=7.6,1.1 \mathrm{~Hz}$, $1 \mathrm{H}), 7.64-7.62(\mathrm{~m}, 2 \mathrm{H}), 7.58(\mathrm{td}, J=7.5,1.2 \mathrm{~Hz}, 1 \mathrm{H}), 7.55-7.53(\mathrm{~m}, 2 \mathrm{H}), 2.22(\mathrm{~s}, 3 \mathrm{H}) \mathrm{ppm} .{ }^{13} \mathrm{C}$ NMR $\left(151 \mathrm{MHz}, \mathrm{DMSO}-d_{6}, 25^{\circ} \mathrm{C}\right) \delta=169.4,168.3,166.2,157.2,144.6,143.5,140.5,138.6$, $136.8,134.5,132.2,131.8,130.9,128.8,128.3(q, J=31.7 \mathrm{~Hz}), 125.8(q, J=3.0 \mathrm{~Hz}), 124.7(q$, $J=273.0 \mathrm{~Hz}), 119.6,105.0,11.2,6.3 .{ }^{19} \mathrm{~F} \mathrm{NMR}\left(565 \mathrm{MHz}, \mathrm{DMSO}-d_{6}, 25{ }^{\circ} \mathrm{C}\right) \delta=-60.9$. MS $m / z 516.3=[\mathrm{M}+\mathrm{H}]^{+}$, calculated for $\mathrm{C}_{25} \mathrm{H}_{20} \mathrm{~F}_{3} \mathrm{~N}_{3} \mathrm{O}_{4} \mathrm{~S} m / z=515.1$.

4'-(Trifluoromethyl)-N-(4-(N-(2-(trifluoromethyl)phenyl)sulfamoyl)phenyl)-[1,1'-biphenyl]-2carboxamide (10p), white solid, m.p. $160-161^{\circ} \mathrm{C}$. ${ }^{1} \mathrm{H}$ NMR $\left(600 \mathrm{MHz}, \mathrm{DMSO}-\mathrm{d}_{6}, 25{ }^{\circ} \mathrm{C}\right)$ $\delta=10.77(\mathrm{~s}, 1 \mathrm{H}), 9.86(\mathrm{~s}, 1 \mathrm{H}), 7.76-7.73(\mathrm{~m}, 4 \mathrm{H}), 7.72-7.69(\mathrm{~m}, 4 \mathrm{H}), 7.64-7.62(\mathrm{~m}, 2 \mathrm{H}), 7.61-$ $7.57(\mathrm{~m}, 2 \mathrm{H}), 7.56-7.53(\mathrm{~m}, 2 \mathrm{H}), 7.46-7.44(\mathrm{~m}, 1 \mathrm{H}), 7.06(\mathrm{~d}, J=8.0 \mathrm{~Hz}, 1 \mathrm{H}) \mathrm{ppm} .{ }^{13} \mathrm{C}$ NMR $\left(151 \mathrm{MHz}, \mathrm{DMSO}-d_{6}, 25^{\circ} \mathrm{C}\right) \delta=168.4,144.6,143.2,138.6,136.9,135.8,134.7,133.7,131.8$, $130.9,130.7,130.1,129.7,129.6,128.8,127.8,127.5,126.6$ (q, $J=28.7 \mathrm{~Hz}), 125.7(q, J=3.8 \mathrm{~Hz})$, $125.4(\mathrm{q}, J=4.5 \mathrm{~Hz}), 123.8,123.7(\mathrm{q}, J=273.3 \mathrm{~Hz}), 122.9(\mathrm{q}, J=274.0 \mathrm{~Hz}), 119.7 .{ }^{19} \mathrm{~F}$ NMR $\left(565 \mathrm{MHz}, \mathrm{DMSO}-d_{6}, 25{ }^{\circ} \mathrm{C}\right) \delta=-58.0,-60.9$. MS $m / z 565.5=[\mathrm{M}+\mathrm{H}]^{+}$, calculated for $\mathrm{C}_{27} \mathrm{H}_{18} \mathrm{~F}_{6} \mathrm{~N}_{2} \mathrm{O}_{3} \mathrm{~S} m / z=564.0$.

2-(6-Chloro-9H-carbazol-2-yl)-N-(4-(N-(2-(trifluoromethyl)phenyl)sulfamoyl)phenyl)propanamide (10q), white solid, m.p. 159-160 ${ }^{\circ} \mathrm{C} .{ }^{1} \mathrm{H}$ NMR $\left(600 \mathrm{MHz}, \mathrm{DMSO}-\mathrm{d}_{6}, 25^{\circ} \mathrm{C}\right) \delta=11.39(\mathrm{~s}, 1 \mathrm{H})$, $10.52(\mathrm{~s}, 1 \mathrm{H}), 9.83(\mathrm{~s}, 1 \mathrm{H}), 8.17(\mathrm{~d}, J=2.1 \mathrm{~Hz}, 1 \mathrm{H}), 8.11(\mathrm{~d}, J=8.1 \mathrm{~Hz}, 1 \mathrm{H}), 7.81(\mathrm{~d}, J=8.9 \mathrm{~Hz}$, 2H), 7.72-7.65 (m, 3H), 7.56-7.51 (m, 2H), $7.48(\mathrm{~d}, J=8.6 \mathrm{~Hz}, 1 \mathrm{H}), 7.43-7.34(\mathrm{~m}, 2 \mathrm{H}), 7.23$ $(\mathrm{dd}, J=8.2,1.4 \mathrm{~Hz}, 1 \mathrm{H}), 7.00(\mathrm{~d}, J=8.0 \mathrm{~Hz}, 1 \mathrm{H}), 4.05-4.02(\mathrm{~m}, 1 \mathrm{H}), 1.52(\mathrm{~d}, J=7.0 \mathrm{~Hz}, 3 \mathrm{H})$ ppm. ${ }^{13} \mathrm{C}$ NMR $\left(151 \mathrm{MHz}, \mathrm{DMSO}-d_{6}, 25{ }^{\circ} \mathrm{C}\right) \delta=173.6,141.0,140.4,138.8,133.6,128.4,127.5$ (q, $J=4.5 \mathrm{~Hz}), 125.6,124.1,123.3,121.1,121.0,120.1,119.3,119.2,112.8,110.1,47.0,19.5$. ${ }^{19} \mathrm{~F}$ NMR $\left(565 \mathrm{MHz}, \mathrm{DMSO}-d_{6}, 25^{\circ} \mathrm{C}\right) \delta=-57.9$. MS $m / z 572.4=[\mathrm{M}+\mathrm{H}]^{+}$, calculated for $\mathrm{C}_{28} \mathrm{H}_{21} \mathrm{ClF}_{3} \mathrm{~N}_{3} \mathrm{O}_{3} \mathrm{~S} m / z=571.0$.

2-(6-Chloro-9H-carbazol-2-yl)-N-(4-(N-(2-phenoxyphenyl)sulfamoyl)phenyl)propanamide (10r),

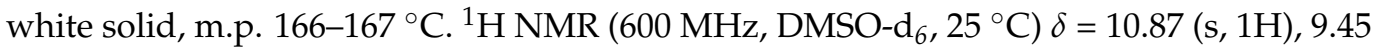
$(\mathrm{s}, 1 \mathrm{H}), 8.56(\mathrm{~d}, J=2.9 \mathrm{~Hz}, 1 \mathrm{H}), 8.26(\mathrm{~d}, J=7.7 \mathrm{~Hz}, 1 \mathrm{H}), 7.77-7.66(\mathrm{~m}, 3 \mathrm{H}), 7.59-7.50(\mathrm{~m}, 3 \mathrm{H})$, 7.35-7.31 (m, 2H), 7.28-7.22 (m, 4H), $7.06(\mathrm{~s}, 1 \mathrm{H}), 4.04(\mathrm{q}, J=7.0 \mathrm{~Hz}, 1 \mathrm{H}), 1.21(\mathrm{~d}, J=7.0 \mathrm{~Hz}$, $3 \mathrm{H}) \mathrm{ppm} .{ }^{13} \mathrm{C}$ NMR $\left(151 \mathrm{MHz}, \mathrm{DMSO}-d_{6}, 25{ }^{\circ} \mathrm{C}\right) \delta=170.8,156.3,148.8,147.8,142.0,140.1$, $139.8,139.2$, 139.1, 136.4, 133.7, 131.4, 129.7, 128.5, 128.2, 128.1, 127.5, 127.4, 127.3, 127.2, 
120.4, 111.8, 60.2, $21.2 \mathrm{ppm}$. MS $m / z 596.4=[\mathrm{M}+\mathrm{H}]^{+}$, calculated for $\mathrm{C}_{33} \mathrm{H}_{26} \mathrm{ClN}_{3} \mathrm{O}_{4} \mathrm{~S}$ $m / z=595.1$.

Bioassays: The in vitro cytotoxicity of the novel carbazole derivatives against human melanoma (A875), human hepatocellular liver carcinoma (HepG2), and a subclone of African green monkey kidney cell line MA-104 (MARC145) cell lines was evaluated using the MTT assay. All data were analyzed with SPSS software, and the 50\% inhibitory concentrations $\left(\mathrm{IC}_{50}\right)$ of each compound for the different cell lines were determined. All assays were performed in triplicate on three independent experiments.

Supplementary Materials: The following are available online. Instrumentation and chemicals, and Spectroscopy for target compounds.

Author Contributions: Conceptualization, S.K., W.F. and H.H.; methodology, W.H., S.K. and L.S.; validation, M.L., Z.Z. and F.L.; formal analysis, S.K. and W.H.; investigation, T.L., S.W. and D.H.; writing-original draft preparation, W.H. and S.K.; writing-review and editing, W.F. and H.H.; supervision, K.W. and R.Z.; funding acquisition, S.K. and H.H. All authors have read and agreed to the published version of the manuscript.

Funding: This research was funded by the Innovation and Application of Key Technologies of Quality Improving and Efficiency Increasing of Fengtou Ginger Industry (2020-620-002-06), and by the Natural Science Foundation of Hubei Province (2020CFB717).

Institutional Review Board Statement: Not applicable.

Informed Consent Statement: Not applicable.

Data Availability Statement: The data presented in this research are available on request from the corresponding authors.

Acknowledgments: The authors gratefully acknowledge the partial support from the Youth Science Foundation of Hubei Academy of Agricultural Sciences (2021NKYJJ17), the Key Laboratory of Integrated Pest Management in Crops in Central China, the Ministry of Agriculture, the Key Laboratory for Crop Diseases, Insect Pests, and Weeds Control in Hubei Province (2020ZTSJJ5), and the Program for Leading Talents of Hubei Academy of Agricultural Sciences (L2018031).

Conflicts of Interest: The authors declare no conflict of interest.

Sample Availability: Samples of the compounds $\mathbf{8 a}-\mathbf{d}$ are available from the authors.

\section{References}

1. Newman, D.J.; Cragg, G.M. Natural Products as Sources of New Drugs over the Nearly Four Decades from 01/1981 to 09/2019. J. Nat. Prod. 2020, 83, 770-803. [CrossRef] [PubMed]

2. Newman, D.J.; Cragg, G.M. Natural Products as Sources of New Drugs from 1981 to 2014. J. Nat. Prod. 2016, 79, 629-661. [CrossRef] [PubMed]

3. Rodrigues, T.; Reker, D.; Schneider, P.; Schneider, G. Counting on Natural Products for Drug Design. Nat. Chem. 2016, 8, 531-541. [CrossRef] [PubMed]

4. $\quad$ Fang, Y.; Li, H.; Ji, B.; Cheng, K.; Wu, B.; Li, Z.; Zheng, C.; Hua, H.; Li, D. Renieramycin-Type Alkaloids from Marine-Derived Organisms: Synthetic Chemistry, Biological Activity and Structural Modification. Eur. J. Med. Chem. 2021, 210, 113092. [CrossRef]

5. Ren, X.; Xie, X.; Chen, B.; Liu, L.; Jiang, C.; Qian, Q. Marine Natural Products: A Potential Source of Anti-Hepatocellular Carcinoma Drugs. J. Med. Chem. 2021, 64, 7879-7899. [CrossRef]

6. Schulz, G.; Victoria, C.; Kirschning, A.; Steinmann, E. Rocaglamide and Silvestrol: A Long Story from Anti-tumor to AntiCoronavirus Compounds. Nat. Prod. Rep. 2021, 38, 18-23. [CrossRef]

7. Ren, Y.; Kinghorn, A.D. Development of Potential Antitumor Agents from The Scaffolds of Plant-derived Terpenoid Lactones. J. Med. Chem. 2020, 63, 15410-15448. [CrossRef]

8. Kwon, Y.; Song, J.; Lee, H.; Kim, E.-Y.; Lee, K.; Lee, S.K.; Kim, S. Design, Synthesis, and Biological Activity of Sulfonamide Analogues of Antofine and Cryptopleurine as Potent and Orally Active Antitumor Agents. J. Med. Chem. 2015, 58, 7749-7762. [CrossRef]

9. Lad, N.P.; Kulkarni, S.; Sharma, R.; Mascarenhas, M.; Kulkarni, M.R.; Pandit, S.S. Piperlongumine Derived Cyclic Sulfonamides (sultams): Synthesis and In Vitro Exploration for Therapeutic Potential Against HeLa Cancer Cell Lines. Eur. J. Med. Chem. 2017, 126, 870-878. [CrossRef] 
10. Liu, Y.; Wu, Y.; Sun, L.; Gu, Y.; Hu, L. Synthesis and Structure-Activity Relationship Study of Water-soluble Carbazole Sulfonamide Derivatives as New Anticancer Agents. Eur. J. Med. Chem. 2020, 191, 112181. [CrossRef]

11. Ahmed, M.F.; Santali, E.Y. Discovery of Pyridine-sulfonamide Hybrids as A New Scaffold for The Development of Potential VEGFR-2 Inhibitors and Apoptosis Inducers. Bioorg. Chem. 2021, 111, 104842. [CrossRef] [PubMed]

12. Kachaeva, M.V.; Hodyna, D.M.; Semenyuta, I.V.; Pilyo, S.G.; Prokopenko, V.M.; Kovalishyn, V.V.; Metelytsia, L.O.; Brovarets, V.S. Design, Synthesis and Evaluation of Novel Sulfonamides as Potential Anticancer Agents. Comput. Biol. Chem. 2018, 74, 294-303. [CrossRef] [PubMed]

13. Sharma, P.; Dayma, V.; Dwivedi, A.; Baroliya, P.K.; Tripathi, I.P.; Vanangamudi, M.; Chauhan, R.S.; Goswami, A.K. Synthesis of Sulpha Drug Based Hydroxytriazene Derivatives: Anti-diabetic, Antioxidant, Anti-inflammatory Activity and Their Molecular Docking Studies. Bioorg. Chem. 2020, 96, 103642. [CrossRef]

14. Abdel-Aziz, A.A.-M.; Angeli, A.; El-Azab, A.S.; Hammouda, M.E.A.; El-Sherbeny, M.A.; Supuran, C.T. Synthesis and Antiinflammatory Activity of Sulfonamides and Carboxylates Incorporating Trimellitimides: Dual Cyclooxygenase/Carbonic Anhydrase Inhibitory Actions. Bioorg. Chem. 2019, 84, 260-268. [CrossRef] [PubMed]

15. Wang, C.; Pei, Y.; Wang, L.; Li, S.; Jiang, C.; Tan, X.; Dong, Y.; Xiang, Y.; Ma, Y.; Liu, G. Discovery of (1H-Pyrazolo[3,4-c]pyridin-5-yl) Sulfonamide Analogues as Hepatitis B Virus Capsid Assembly Modulators by Conformation Constraint. J. Med. Chem. 2020, 63, 6066-6089. [CrossRef]

16. He, F.; Shi, J.; Wang, Y.; Wang, S.; Chen, J.; Gan, X.; Song, B.; Hu, D. Synthesis, Antiviral Activity, and Mechanisms of Purine Nucleoside Derivatives Containing A Sulfonamide Moiety. J. Agric. Food Chem. 2019, 67, 8459-8467. [CrossRef] [PubMed]

17. Mujumdar, P.; Poulsen, S.-A. Natural Product Primary Sulfonamides and Primary Sulfamates. J. Nat. Prod. 2015, 78, 1470-1477. [CrossRef]

18. Kende, A.S.; Liu, K.; Jos Brands, K.M. Total Synthesis of (-)-Altemicidin: A Novel Exploitation of The Potier-polonovski Rearrangement. J. Am. Chem. Soc. 1995, 117, 10597-10598. [CrossRef]

19. Peng, Y.; Cao, L.; Liu, Y.; Huang, R. Sargassulfamide A, An Unprecedented Amide Derivative from the Seaweed Sargassum naozhouense. Chem. Nat. Compd. 2020, 56, 98-100. [CrossRef]

20. Xu, Y.; Liang, X.; Li, Y.; Liang, Z.; Huang, W.; Zhang, H.; Jiang, Y.; Cui, J.; Song, X. Arylsulfonamides from The Roots and Rhizomes of Tupistra chinensis Baker. Nat. Prod. Commun. 2020, 15, 1-5. [CrossRef]

21. Xu, T.; Shi, L.; Zhang, Y.; Wang, K.; Yang, Z.; Ke, S. Synthesis and Biological Evaluation of Marine Alkaloid-oriented $\beta$-Carboline Analogues. Eur. J. Med. Chem. 2019, 168, 293-300. [CrossRef] [PubMed]

22. Wang, S.; Bao, L.; Song, D.; Wang, J.; Cao, X.; Ke, S. Amino Acid-oriented Poly-substituted Heterocyclic Tetramic Acid Derivatives as Potential Antifungal Agents. Eur. J. Med. Chem. 2019, 179, 567-575. [CrossRef] [PubMed]

23. Ke, S.; Zhang, Z.; Liu, M.; Fang, W.; Huang, D.; Wan, Z.; Zhou, R.; Wang, K.; Shi, L. Synthesis and Bioevaluation of Novel Steroidal Isatin Conjugates Derived from Epiandrosterone/Androsterone. J. Enzyme Inhib. Med. Chem. 2019, 34, 1607-1614. [CrossRef] [PubMed]

24. Huang, D.; Wang, S.; Song, D.; Cao, X.; Huang, W.; Ke, S. Discovery of $\gamma$-Lactam Alkaloid Derivatives as Potential Fungicidal Agents Targeting Steroid Biosynthesis. J. Agric. Food Chem. 2020, 68, 14438-14451. [CrossRef] [PubMed]

25. Huang, W.; Gao, Z.; Zhang, Z.; Fang, W.; Wang, Z.; Wan, Z.; Shi, L.; Wang, K.; Ke, S. Selective and Effective Anticancer Agents: Synthesis, Biological Evaluation and Structure-Activity Relationships of Novel Carbazole Derivatives. Bioorg. Chem. 2021, 113, 104991. [CrossRef]

26. Ke, S.; Zhang, Z.; Shi, L.; Liu, M.; Fang, W.; Zhang, Y.; Wu, Z.; Wan, Z.; Long, T.; Wang, K. An Efficient Synthesis and Bioactivity Evaluation of Oxazole-containing Natural Hinduchelin A-D and Their Derivatives. Org. Biomol. Chem. 2019, 17, 3635-3639. [CrossRef]

27. Mahmood, N.; Rasool, N.; Ikram, H.M.; Hashmi, M.A.; Mahmood, T.; Zubair, M.; Ahmad, G.; Rizwan, K.; Rashid, T.; Rashid, Y. Synthesis of 3,4-Biaryl-2,5-Dichlorothiophene through Suzuki Cross-Coupling and Theoretical Exploration of Their Potential Applications as Nonlinear Optical Materials. Symmetry 2018, 10, 766. [CrossRef]

28. Sial, N.; Rasool, N.; Rizwan, K.; Altaf, A.A.; Ali, S.; Malik, A.; Zubair, M.; Akhtar, A.; Kausar, S.; Shah, S.A.A. Efficient Synthesis of 2,3-Diarylbenzo[b]thiophene Molecules Through Palladium (0) Suzuki-Miyaura Cross-coupling Reaction and Their Antithrombolyitc, Biofilm Inhibition, Hemolytic Potential and Molecular Docking Studies. Med. Chem. Res. 2020, 29, 1486-1496. [CrossRef]

29. Masand, N.; Gupta, S.P.; Khosa, R.L. N-Substituted Aryl Sulphonamides as Potential Anti-Alzheimer's Agents: Design, Synthesis and Biological Evaluation. Curr. Comput. Aided Drug Des. 2018, 14, 338-348. [CrossRef]

30. Alley, M.C.; Scudiero, D.A.; Monks, A.; Hursey, M.L.; Czerwinski, M.J.; Fine, D.L.; Abbott, B.J.; Mayo, J.G.; Shoemaker, R.H.; Boyd, M.R. Feasibility of Drug Screening with Panels of Human Tumor Cell Lines using A Microculture Tetrazolium Assay. Cancer Res. 1988, 48, 589-601.

31. Ke, S.; Shi, L.; Cao, X.; Yang, Q.; Liang, Y.; Yang, Z. Heterocycle-Functional Gramine Analogues: Solvent- and Catalyst-free Synthesis and Their Inhibition Activities Against Cell Proliferation. Eur. J. Med. Chem. 2012, 54, 248-254. [CrossRef] [PubMed]

32. Meanwell, N.A. Fluorine and Fluorinated Motifs in The Design and Application of Bioisosteres for Drug Design. J. Med. Chem. 2018, 61, 5822-5880. [CrossRef] [PubMed] 
33. Xi, D.; Niu, Y.; Li, H.; Noha, S.M.; Temml, S.M.; Schuster, D.; Wang, C.; Xu, F.; Xu, P. Discovery of Carbazole Derivatives as Novel Allosteric MEK Inhibitors by Pharmacophore Modeling and Virtual Screening. Eur. J. Med. Chem. 2019, 178, 802-817. [CrossRef] [PubMed]

34. Wang, B.-Y.; Lin, Y.-C.; Lai, Y.-T.; Ou, J.-Y.; Chang, W.-W.; Chu, C.-C. Targeted Photoresponsive Carbazole-coumarin and Drug Conjugates for Efficient Combination Therapy in Leukemia Cancer Cells. Bioorg. Chem. 2020, 100, 103904. [CrossRef]

35. Ma, X.-L.; Zhu, S.-S.; Liu, Y.; Chen, H.-W.; Shi, Y.-T.; Zeng, K.-W.; Tu, P.-F.; Jiang, Y. Carbazole Alkaloids with Potential Cytotoxic Activities Targeted on PCK2 Protein from Murraya Microphylla. Bioorg. Chem. 2021, 114, 105113. [CrossRef] 